\title{
MENINGKATKAN KINERJA GURU MELALUI TEKNIK SUPERVISI OBSERVASI KELAS DI SMP NEGERI 1 KEDUNGPRING KABUPATEN LAMONGAN
}

\author{
Mu'ad \\ muad.0204@gmail.com \\ Pengawas SMP Dinas Pendidikan Kab. Lamongan
}

\begin{abstract}
ABSTRAK
Penelitian difokuskan pada penyempurnaan supervisi pengajaran dengan teknik observasi kelas yang dilakukan oleh kepala sekolah melalui penelitian tindakan. Penelitian ini mempunyai tujuan untuk mengetahui pelaksanaan kegiatan supervisi pengajaran dengan teknik observasi kelas yang dilakukan oleh kepala sekolah melalui penelitian tindakan dan kinerja guru dalam perencanaan dan proses pembelajaran di kelas pada saat disupervisi oleh kepala sekolah. Penelitian Tindakan ini dilaksanakan di SMP Negeri 1 Kedungpring Kabupaten Lamongan semester ganjil tahun pelajaran 2017/2018 sebanyak 3 siklus dengan guru mata pelajaran yang berbeda pada tiap-tiap siklus. Hasil penelitian, pada siklus pertama kepala sekolah belum memahami pendekatan/ketepatan penggunaan teknik supervisi dan etika penerapan teknik supervisi observasi kelas dengan benar. Siklus kedua, kepala sekolah sudah memahami dan menerapkannya dengan baik pada saat mensupervisi guru. Sampai dengan siklus ketiga, menunjukkan ketrampilan kepala sekolah dalam mensupervisi guru dengan adanya pengembangan instrumen supervisi observasi kelas yang disesuaikan dengan situasi dan kondisi sekolah. Kinerja guru SMP Negeri 1 Kedungpring Kabupaten Lamongan dalam perencanaan pembelajaran menunjukkan rata-rata peningkatan dari siklus pertama $(2,88)$, siklus kedua $(3,44)$, dan siklus ketiga $(4,01)$. Ini artinya dalam perencanaan pembelajaran yang dilakukan guru sudah mendekati tujuan pembinaan kinerja melalui supervisi observasi kelas. Demikian pula pada kinerja guru dalam proses pembelajaran di kelas menunjukkan rata-rata peningkatan dari siklus pertama $(3,46)$, siklus kedua $(3,91)$, dan siklus ketiga $(4,88)$. Berdasarkan hasil temuan di atas, penggunaan teknik supervisi observasi kelas oleh kepala sekolah agar tetap diintensifkan. Semakin sering kepala sekolah melakukan supervisi observasi kelas, maka kemampuan dan ketrampilan dalam mensupervisi guru semakin meningkat dengan baik. Hal ini akan berdampak positif pada kinerja guru dalam merencanakan dan melaksanakan proses pembelajaran.
\end{abstract}

Kata Kunci: Kinerja Guru; Teknik Supervisi Observasi Kelas

\section{PENDAHULUAN}

Dewasa ini pendidikan di Indonesia tetap menjadi bahan perbincangan yang menarik perhatian, bukan saja bagi para profesional bahkan juga masyarakat luas. Pemerintah sendiri sendiri sesungguhnya telah berupaya memperbaiki dan mengembangkan dan mengembangkan pendidikan di Indonesia. Upaya ini dilakukan tidak hanya bertujuan pemerataan kesempatan untuk mendapatkan pendidikan, tetapi juga peningkatan mutu pendidikan. Kepala Sekolah mempunyai posisi yang penting dalam memelihara dan memperbaiki kualitas sekolah, disiplin dalam melaksanakan tugas dan kewajibannya dalam upaya mencapai tujuan pendidikan. Usaha pembinaan, pengembangan dan pengendalian tersebut sangat diperlukan penerapan fungsi-fungsi manajemen pendidikan yang sangat penting artinya dalam upaya meningkatkan profesionalisme tenaga staf, terutama guru-guru sebagai tenaga operasional pendidikan. Supervisi diperlukan dalam proses pengajaran berdasarkan dua hal penting, yaitu: (1) perkembangan kurikulum yang merupakan gejala kemajuan pendidikan, (2) perkembangan personel senantiasa merupakan upaya yang terus menerus dalam suatu organisasi.

Bolla, JL (1985) mengemukakan mengapa supervisi itu penting, (1) guru memiliki kemampuan yang terbatas untuk mengendalikan dan menganalisis tingkah lakunya maupun tingkah laku siswanya dalam proses belajar mengajar, dan (2) 
proses belajar mengajar adalah suatu proses yang komplek dan unik sehingga guru sulit memisahkan, merefleksikan dan menyadari tingkah lakunya sementara ia sedang mengelola proses belajar mengajar. Pada sisi lain, Boardman (1967) mengemukakan bahwa tanggungjawab kepala sekolah sebagai supervisor (pembina) guru-guru mencakup kegiatan dalam membimbing guru agar dapat memahami lebih jelas tentang masalahmasalah dan kebutuhan murid dan kemudian membantu menyelesaikannya, membantu guru mengatasi kesulitan mengajarnya, memberi bimbingan dengan cara bijaksana kepada guru baru melalui proses orientasi, membantu guru dalam memperoleh kecakapan mengajar yang lebih baik dengan menggunakan sebagai metode mengajar, membantu guru memperkaya pengalaman belajar sehingga mampu menciptakan suasana pengajaran kondusif, membantu guru agar mereka lebih mengerti tentang makna media pengajaran yang dipergunakannya, menumbuhkan moral yang tinggi dalam pelaksanaan tugas sekolah pada seluruh staf, dan memberi layanan kepada guru agar ia dapat menggunakan seluruh kemampuannya dalam melaksanakan tugas.

Maka dapat dikatakan, bahwa fungsi kepala sekolah sebagai supervisor adalah memberikan layanan kepada guruguru dalam upaya meningkatkan kemampuan dan kualitas profesionalnya, yaitu menciptakan kondisi belajar mengajar yang lebih baik. Supervisi yang dilakukan kepala sekolah itu, antara lain untuk meningkatkan kinerja guru-guru dalam kegiatan belajar mengajar, sehingga diharapkan memenuhi misi pengajaran yang diembannya. Namun demikian dalam kenyataannya di lapangan, masih banyak dijumpai kepala sekolah dan guru-guru SMP Negeri di kabupaten Lamongan masih banyak dijumpai kendala dan persoalan yang berkaitan dengan penerapan/penggunaan teknik supervisi. Secara umum persoalan tersebut meliputi: pelaksanaan supervisi masih menggunakan jalur satu arah yaitu dari kepala sekolah sebagai atasan terhadap guru sebagai bawahan, adanya keluhan dari guru tentang perilaku kepala sekolah, sulitnya memadukan keinginan antara kepala sekolah dan guru tentang teknik supervisi yang harus digunakan, pelaksanaan supervisi dilakukan pada alokasi waktu yang amat terbatas, dan supervisi kerap kali dilakukan atas inisiatif dan keinginan kepala sekolah semata. Untuk itulah peneliti tertarik untuk mengadakan Penelitian Tindakan (PT) yang berjudul "Meningkatkan Kinerja Guru Melalui Teknik Supervisi Observasi Kelas di SMP Negeri 1 Kedungpring Kabupaten Lamongan". Adapun tujuan dari penelitian: (a) Untuk mengetahui perkembangan pelaksanaan kegiatan supervisi observasi kelas yang dilakukan oleh kepala SMP Negeri 1 Kedungpring Kabupaten Lamongan. (b) Untuk mengetahui perkembangan kinerja/kemampuan guru SMP Negeri 1 Kedungpring Kabupaten Lamongan dalam perencanaan proses pembelajaran ketika disupervisi kepala sekolah melalui supervisi observasi kelas. (c) Untuk mengetahui perkembangan kinerja/kemampuan guru SMP Negeri 1 Kedungpring Kabupaten Lamongan dalam proses pembelajaran ketika disupervisi kepala sekolah melalui supervisi observasi kelas.

\section{METODE}

Penelitian ini merupakan penelitian tindakan di SMP Negeri 1 Kedungpring Kabupaten Lamongan, sehingga jenis penelitiannya akan dirancang dengan menggunakan penelitian tindakan (Action Research). Teknik penentuan sasaran yang berorientasi kepada pemilihan sasaran spesifik yaitu SMP Negeri 1 Kedungpring Kabupaten Lamongan yang 
menjadi wilayah kerja binaan peneliti selaku pengawas sekolah selama tahun pelajaran 2017/2018. Dalam penelitian ini peneliti mengambil kepala SMP Negeri 1 Kedungpring Kabupaten Lamongan sebagai subyek penelitian. Adapun alasan peneliti memilih kepala SMP Negeri 1 Kedungpring Kabupaten Lamongan ini dengan pertimbangan, bahwa SMP Negeri 1 Kedungpring Kabupaten Lamongan ini menjadi wilayah kerja binaan peneliti, sehingga penelitian dapat dilaksanakan secara efektif dan efisien baik dari segi waktu maupun pendanaan. Disamping itu, SMP Negeri 1 Kedungpring Kabupaten Lamongan ini dalam penilaian kinerja yang dilakukan oleh tim pengawas dikmenum kabupaten Lamongan khususnya penilaian supervisi akademik terhadap pelaksanaan supervisi observasi kelas yang dilakukan kepala sekolah dalam perencanaan dan proses pembelajaran di kelas menunjukkan kualitas yang baik.

Teknik pengumpulan data yang digunakan dalam penelitian ini, sesuai dengan desain penelitian yang telah diuraikan adalah: (1) Observasi: langkah penting pertama yang ditempuh observer pada tahap ini adalah penciptaan pra kondisi observasi. Langkah ini ditunjukkan dengan penciptaan suasana kerja yang akrab antara peneliti dengan kepala sekolah atau antara supervisor dengan guru. Langkah ini ditempuh guna menciptakan situasi yang kondusif bagi pelaksanaan observasi yang efektif dan efisien, sehingga data, fakta yang terkumpul mencerminkan keadaan yang sebenarnya. Observasi ini digunakan untuk memperoleh data dan fakta tentang: (a) Kemampuan dan ketrampilan kepala sekolah dalam mensupervisi guru dengan cara peneliti mengikuti kepala sekolah berkunjung ke kelas untuk melakukan kegiatan supervisi pengajaran dengan teknik supervisi observasi kelas, mulai dari perencanaan siklus I sampai dengan pelaksanaan siklus yang terakhir. (b)
Kemampuan guru dalam perencanaan dan proses pembelajaran di kelas pada saat supervisi oleh kepala sekolah. (2) Wawancara adalah percakapan dengan maksud tertentu yang dilakukan dua pihak yaitu si pewawancara (interviewer) yang mengajukan pertanyaan dan yang diwawancarai (interviewee) yang memberikan jawaban atas pertanyaan tersebut (Maleong L, 2003) atau bentuk komunikasi verbal yang bertujuan memperoleh informasi atau teknik pengumpulan data dengan cara komunikasi langsung dengan responden baik dalam situasi yang sebenarnya maupun buatan (Surachmad W, 2009 dalam Syukur, 2010). Penelitian ini menggunakan wawancara tidak terstruktur untuk memperoleh data tentang pendapat kepala sekolah terhadap adanya inovasi supervisi pengajaran yang dikaitkan dengan penelitian tindakan, perbaikan konsep supervisi sampai dengan instrumen supervisinya, dan hasil kegiatan supervisi yang telah dilakukan, khususnya supervisi pengajaran dengan teknik supervisi observasi kelas.

\section{HASIL PENELITIAN DAN PEMBAHASAN}

\section{Hasil Wawancara Awal}

Wawancara dilakukan sebelum melakukan penelitian, wawancara difokuskan kepada pelaksanaan supervisi observasi kelas yang telah dilakukan oleh kepala sekolah dan hasil wawancara adalah sebagai berikut:

a. Program perencanaan kegiatan supervisi observasi kelas untuk satu tahun pelajaran ditentukan sbb:

1) Untuk semester gasal sebanyak 60 $\%$ dari jumlah guru

2) Untuk Semester ganjil sebanyak 40 $\%$ dari jumlah guru

b. Frekuensi penggunaan supervisi observasi kelas diatur sbb: 
1) Dibuat jadual kegiatan supervisi observasi kelas untuk diketahui oleh semua guru mata pelajaran dan dikelompokkan per mata pelajaran

2) Satu semester minimal satu kali supervisi observasi kelas

3) Observasi kelas dilakukan dengan pemberitahuan atau atas permintaan

4) Wawancara/percakapan individual untuk mengetahui masalah dan kesulitan yang dialami guru pada umumnya dilaksanakan sebelum dan sesudah pelaksanaan supervisi

5) Percakapan individual dalam suasana non formal dan penuh keakraban

6) Memberi masukan kepada guru yang disupervisi agar melakukan evaluasi diri untuk pembenahan dan pertemuan berikutnya

c. Ketepatan penggunaan teknik supervisi observasi kelas.

1) Menggunakan instrumen (catatan rekaman) observasi

2) Diskusi hasil observasi dipakai untuk menyusun langkah-langkah pembinaan yang terprogram dan sistematis

3) Program supervisi observasi kelas yang berkesinambungan tanpa mengganggu proses pembelajaran

4) Pembinaan diarahkan untuk memberikan motivasi penerapan eksperimentasi metode pengajaran yang baru

5) Sebelum maupun setelah proses pembelajaran disediakan waktu untuk bertemu dan bertukar pikiran tentang pelajaran yang dilakukan.

\section{Kegiatan Supervisi Observasi Kelas Siklus I}

1. Perencanaan (planning)

Kegiatan yang dilaksanakan pada siklus ini adalah merencanakan tindakan dengan jalan mengkondisikan subyek penelitian yaitu kepala sekolah sebagai supervisor dan guru sebagai pihak yang akan disupervisi. Pada tahap ini peneliti menjelaskan tentang konsep supervisi observasi kelas beserta instrumeninstrumen yang telah disiapkan oleh peneliti, dan hal-hal apa yang harus dipersiapkan oleh kepala sekolah dan guru. Perencanaan ini dibuat dengan tidak lepas dari hasil wawancara awal tentang kondisi obyektif kegiatan supervisi di SMP Negeri 1 Kedungpring Kabupaten Lamongan. Setelah memperoleh kejelasan tentang apa yang akan dilakukannya, peneliti bersama kepala sekolah dan guru siap melaksanakan tahapan-tahapan yang sudah disepakati baik menyangkut kelas sasaran, waktu yang dibutuhkan, materi pembelajaran, pendekatan atau metode yang digunakan, dan media pembelajarannya yang digunakan.

2. Pelaksanaan (Acting)

Pada tahap ini, peneliti memasuki ruang kelas dan melakukan pengamatan terhadap kegiatan kepala sekolah mensupervisi guru dengan menggunakan instrumen supervisi observasi kelas yang telah disapkan. Wawancara dilakukan setelah proses pembelajaran selesai. Pada siklus ini peneliti bekerjasama dengan kepala sekolah berdasarkan informasi yang diperoleh pada studi awal berupa wawasan konseptual yang sudah diidentifikasi atau dirumuskan. Hasil wawancara dari kegiatan tahap ini adalah, pada dasarnya guru ingin mengembangkan potensi dan berusaha memperbaiki atau meningkatkan kinerja dengan cara berdiskusi dengan guru lain atau supervisor/peneliti.

3. Pengamatan (Observating)

Setelah dilakukan pengamatan selama kegiatan supervisi observasi kelas, hasil-hasilnya adalah sebagai berikut: (a) Instrumen yang telah disiapkan peneliti berusaha dipahami oleh kepala sekolah dan bilamana ada hal-hal yang kurang dimengerti selalu didiskusikan dan ditanyakan kepada peneliti, selanjutnya 
menggunakan instrumen supervisi observasi kelas dengan mencatat semua hasil pengamatan. (b) Ada usaha dari kepala sekolah untuk mencoba dan mengembangkan sendiri instrumen observasi kelas dengan mengusulkan agar kolom skala nilai/penilaian diganti menjadi kolom pemberian komentar dan saran untuk setiap kegiatan yang diamati khususnya yang berkaitan dengan hal-hal yang menyangkut pembelajaran di kelas. (c) Keterlibatan peneliti bersama kepala sekolah dalam diskusi-diskusi yang berlangsung untuk pengembangan instrumen ternyata memberikan semangat dan dorongan bagi kepala sekolah untuk menggunakan instrumen supervisi observasi kelas, hal ini tampak dari hasil pengamatan yang langsung didiskusikan bersama guru yang disupervisi setelah disupervisi. Banyak masukan dan informasi dari kepala sekolah yang harus dilakukan oleh guru untuk perbaikan dan peningkatan kinerjanya misalnya pertanyaan-pertanyaan yang diberikan belum merata pada semua siswa di kelas. (d) Suasana di dalam kelas tampak belum kondusif, pembelajaran terpusat pada guru, pembelajaran disampaikan dengan metode ceramah yang berkepanjangan, tidak ada kesempatan bagi siswa untuk bertanya, demikian pula siswa dipanggil satu persatu pada saat mengabsensi siswa.

4. Refleksi (Reflecting)

Setelah dilakukan pengamatan, maka tahap berikutnya adalah refleksi yang mana hasil refleksinya adalah sebagai berikut: (a) Frekuensi kegiatan supervisi observasi kelas dengan menggunakan instrumen hasil diskusi/kesepakatan bersama peneliti ditingkatkan penggunaannya untuk meningkatkan ketrampilan mensupervisi guru. (b) Keterlibatan guru dalam rencana kegiatan supervisi observasi kelas sangat diperlukan dengan menunjukkan instrumen yang akan digunakan untuk menumbuhkan rasa aman dalam melakukan pembelajaran pada saat kegiatan supervisi berlangsung. (c) Bimbingan dan pembinaan guru untuk menyusun rencana pembelajaran dan pelaksanaan proses pembelajaran harus cepat direspon oleh kepala sekolah sehingga kinerja guru dan aktivitas siswa selama kegiatan pembelajaran berlangsung dapat ditingkatkan. (d) Siklus kedua perlu dilakukan untuk meningkatkan ketrampilan kepala sekolah dalam mensupervisi guru

5. Revisi

Setelah dilakukan refleksi, maka tahap berikutnya adalah melakukan revisi, yaitu: (a) Menyiapkan instrumen yang telah diubah dan disesuaikan dengan kondisi dan situasi sekolah. (b) Instrumen hasil diskusi antara kepala sekolah dengan guru tentang perencanaan kegiatan supervisi observasi kelas dipahami oleh guru yang akan disupervisi

\section{Kegiatan Supervisi Observasi Kelas Siklus II}

1. Perencanaan (planning)

Kegiatan yang dilaksanakan pada siklus kedua ini adalah sama dengan kegiatan pada siklus pertama, yaitu merencanakan tindakan dengan jalan mengkondisikan subyek penelitian yaitu kepala sekolah sebagai supervisor dan guru sebagai pihak yang akan disupervisi. Pada tahap ini peneliti menjelaskan tentang konsep supervisi observasi kelas beserta instrumen-instrumen hasil revisi, dan hal-hal apa yang harus dipersiapkan oleh kepala sekolah dan guru. Perencanaan ini dibuat dengan tidak lepas dari hasil refleksi dan revisi pada siklus pertama tentang pelaksanaan kegiatan supervisi di SMP Negeri 1 Kedungpring Kabupaten Lamongan. Setelah memperoleh kejelasan tentang apa yang akan dilakukannya, peneliti bersama kepala sekolah dan guru siap melaksanakan tahapan-tahapan yang sudah disepakati baik menyangkut kelas sasaran, waktu yang dibutuhkan, materi pembelajaran, pendekatan atau metode 
yang digunakan, dan media pembelajarannya yang digunakan.

2. Pelaksanaan (Acting)

Hasil wawancara dari kegiatan tahap ini adalah, guru menyadari bahwa perubahan aktifitas hasil tindakan/intervensi sangat berpengaruh terhadap peningkatan kinerja dalam perencanaan dan proses pembelajaran.

3. Pengamatan (Observating)

Setelah dilakukan pengamatan selama kegiatan supervisi observasi kelas, hasil-hasilnya adalah sebagai berikut: (a) Penerapan instrumen supervisi observasi yang telah direvisi telah digunakan oleh kepala sekolah. Ketrampilan menggunakan instrumen nampak lebih baik, hal ini ditunjukkan dengan kemampuan kepala sekolah memberikan pembinaan berupa saran-saran yang ditulis pada format isian hasil pengamatan. Pernyataan-pernyataan seperti tidak menghemat waktu apakah sebaiknya presensi itu dilakukan dengan menghitung jumlah siswa yang masuk dibandingkan dengan jumlah siswa yang seharusnya hadir atau dengan memperhatikan tempat duduk siswa yang kosong atau melihat papan absen yang tersedia di kelas. Ungkapan-ungkapan tersebut selalu muncul dalam bentuk tulisan ketika guru yang disupervisi melakukan presensi siswa dengan memanggil satu persatu nama siswa. Demikian pula ketika kepala sekolah mengamati guru yang disupervisi belum nampak adanya motivasi guru kepada siswa agar lebih tertarik dan berminat untuk mengikuti proses pembelajaran yang berlangsung maka komentar/saran yang diberikan adalah 'motivasi siswa untuk mengikuti pembelajaran belum tampak jelas, sebaiknya pertanyaan pada siswa dikorelasikan dengan pemberian motivasi siswa'. Ungkapan-ungkapan yang lain dan bernada penghargaan juga tampak seperti saran/komentar 'cukup baik dilakukan, baik, masih perlu ditingkatkan, dll.' (b) Aktifitas pembelajaran lebih kondusif, interaksi antara guru dan siswa lebih baik, demikian pula sebaliknya. Suasana pembelajaran menyenangkan, guru menanggapi pertanyaan dan merespon siswa dengan memberikan petunjuk dan penjelasan yang berkaitan dengan isi pertanyaan tersebut.

4. Refleksi (Reflecting)

Setelah dilakukan pengamatan, maka tahap berikutnya adalah refleksi yang mana hasil refleksinya adalah sebagai berikut: (a) Sosialisasi tentang perlunya supervisi observasi sebagai salah satu bentuk pembinaan sangat diperlukan. Sosialisasi diarahkan pada pemanfaatan hasil observasi, penggunaan instrumen untuk perbaikan dan peningkatan kinerja serta kemampuan guru dalam merencanakan dan melakukan proses pembelajaran di kelas. (b) Frekuensi penggunaan teknik observasi kelas masih perlu ditingkatkan untuk mengeliminir perbedaan pemahaman konsep tentang ketepatan, etika teknik supervisi observasi kelas serta memberi kesempatan untuk menggunakan instrumen yang sudah disiapkan yang dirancang bersama peneliti untuk memberikan kontribusi dalam meningkatkan ketrampilan kepala sekolah mensupervisi guru. (c) Keterlibatan guru bersama kepala sekolah melakukan diskusi perlu dijaga kontinuitasnya, terutama bagi guru yang akan disupervisi. Diskusi nantinya bisa memberikan solusi/jalan keluar dari persoalan-persoalan pembelajaran yang dihadapi guru. Kesamaan persepsi tentang pemahaman instrumen yang digunakan merupakan bagian dari diskusi tersebut yang selanjutnya diteruskan dengan kesediaan dan kesiapan guru untuk disupervisi sehingga persiapan dan proses pembelajaran dapat berlangsung sesuai dengan prose pembelajaran yang direncanakan. (d) Siklus ketiga masih perlu dilakukan untuk peningkatan ketrampilan kepala sekolah dalam mensupervisi guru. 


\section{Revisi}

Setelah dilakukan refleksi, maka tahap berikutnya adalah melakukan revisi, yaitu: pada dasarnya tata cara pelaksanaan supervisi maupun instrumen supervisi tidak ada revisi, hanya saja bukan berarti tidak ada diskusi. Diskusi masih tetap dilakukan untuk menyamakan persepsi tentang kegiatan supervisi observasi kelas dalam rangka perbaikan dan peningkatan kinerja guru dalam proses pembelajaran.

\section{Kegiatan Supervisi Observasi Kelas Siklus III}

1. Perencanaan (planning)

Kegiatan yang dilaksanakan pada siklus ketiga ini adalah sama dan tidak ada perbedaan dengan kegiatan pada siklus kedua, yaitu merencanakan tindakan dengan jalan mengkondisikan subyek penelitian yaitu kepala sekolah sebagai supervisor dan guru sebagai pihak yang akan disupervisi. Pada tahap ini peneliti menjelaskan tentang konsep supervisi observasi kelas beserta instrumeninstrumen hasil revisi, dan hal-hal apa yang harus dipersiapkan oleh kepala sekolah dan guru. Perencanaan ini dibuat dengan tidak lepas dari hasil refleksi dan revisi pada siklus kedua tentang pelaksanaan kegiatan supervisi di SMP Negeri 1 Kedungpring Kabupaten Lamongan. Setelah memperoleh kejelasan tentang apa yang akan dilakukannya, peneliti bersama kepala sekolah dan guru siap melaksanakan tahapan-tahapan yang sudah disepakati baik menyangkut kelas sasaran, waktu yang dibutuhkan, materi pembelajaran, pendekatan atau metode yang digunakan, dan media pembelajarannya yang digunakan.

2. Pelaksanaan (Acting)

Hasil wawancara menunjukkan bahwa guru memberikan komentar positif terhadap pelaksanaan supervisi. Guru merasa senang karena selama pelaksanaan supervisi dapat dibantu/dibina sehingga meningkatkan kinerjanya dalam perencanaan dan proses pembelajaran.

3. Pengamatan (Observating)

Setelah dilakukan pengamatan selama kegiatan supervisi observasi kelas, hasil-hasilnya adalah sebagai berikut: (a) Proses pembelajaran lebih dinamis, guru lebih percaya diri, penguasaan bahan pelajaran lebih baik, dan penyampaian bahan pembelajaran secara rinci dan sistematis. (b) Suasana demokratis mewarnai kelas, keterlibatan siswa sangat menonjol, dan guru hanya bertindak sebagai fasilitator saja. (c) Kepala sekolah sebagai supervisor lebih trampil menggunakan instrumen supervisi yang telah direvisi. Ketrampilan ditunjukkan dalam pemberian nilai yang sesuai dengan kualifikasi ketrampilan guru dalam menyusun rencana pembelajaran. Ketrampilan mensupervisi juga ditunjukkan dengan pemberian saran/pernyataan yang lebih baik dan kongkrit sesuai dengan performa guru selama proses pembelajaran, komentar/saran ditulis dengan bahasa yang komunikatif, mudah dicerna dan dipahami guru, sehingga memberikan kemudahan bagi guru mengikuti atau melaksanakan saran-saran yang diberikan oleh supervisor (kepala sekolah)

4. Refleksi (Reflecting)

Setelah dilakukan pengamatan, maka tahap berikutnya adalah refleksi yang mana hasil refleksinya adalah: bahwa komitmen dari kepala sekolah dalam upaya perbaikan dan peningkatan ketrampilan mensupervisi guru harus terus dipertahankan dan dikembangkan sesuai dengan situasi dan kondisi sekolah.

5. Revisi

Setelah selesai pelaksanan siklus ketiga, tidak ada yang perlu direvisi dan siklus berikutnya tidak perlu diadakan, karena kepala sekolah dan peneliti sudah cukup puas dengan pelaksanaan supervisi observasi kelas. Kegiatan supervisi observasi kelas dilakukan sesuai dengan 
tata cara dan etika supervisi, tidak ada lagi hubungan atasan bahawan, yang ada justru suasana kolegial, semangat kekeluargaan antara guru dan kepala sekolah. Pembinaan melalui teknik supervisi observasi berdampak pada tumbuhnya semangat dan motivasi guru untuk mengembangkan kreativitas dalam merencanakan dan melaksanakan proses pembelajaran.

\section{Pembahasan}

Dalam bab ini secara khusus akan diuraikan tentang pembahasan atau diskusi hasil penelitian, yaitu tentang beberapa hal penting yang ditemui dalam pelaksanaan penelitian tindakan yang dilaksanakan di SMP Negeri 1 Kedungpring Kabupaten Lamongan. Dalam pelaksanaan supervisi pengajaran, kepala sekolah sering menerapkan apa yang ada di petunjuk pelaksanaan supervisi yang diperoleh dari hasil penataran atau pendidikan dan pelatihan yang diadakan oleh Departemen pendidikan nasional baik tingkat propinsi maupun kabupaten, ataupun menerapkan apa yang diminta oleh atasan kepala sekolah (dalam hal ini Kepala Dinas Pendidikan dan Kebudayaan Kabupaten dan pengawas sekolah) tanpa harus mempelajari teori supervisi pengajaran secara rinci dari berbagai buku supervisi yang ada, sehingga dapat dikatakan bahwa penmgetahuan atau wawasan kepala sekolah tentang supervisi pengajaran sangat terbatas.

Dalam penerapan, sedikit sekali yang diketahui oleh kepala sekolah bahwa sesungguhnya ada perbedaan antara supervisi kunjungan kelas dengan supervisi observasi kelas. Kepala sekolah agak sulit membedakan antara teknik kunjungan kelas dengan teknik observasi kelas. Secara praktis, seringkali kedua teknik ini dilakukan secara bersamaan, padahal perbedaan yang dapat dikemukakan terutama menyangkut tujuan dan tahapan kerja tertentu, seperti dalam kunjungan kelas seorang supervisor dimungkinkan terlibat secara langsung dalam PBM, sedangkan teknik observasi kelas tidak dibenarkan secara langsung. Sebagaimana telah disinggung di atas bahwa kunjungan kelas bertujuan lebih spesifik, sementara observasi lebih luas, mulai dari awal sampai akhir sebuah proses belajar mengajar berlangsung.

Mengenai persamaannya dapat dikemukakan bahwa keduanya membutuhkan terciptanya hubungan yang baik antara guru dan supervisor sebelum dan sesudah supervisi dilakukan. Demikian pula memiliki kesamaan tentang alat dan cara mencatat perilaku guru-guru yang disupervisi. Disamping itu, kedua teknik ini membutuhkan tindak lanjut setelah kedua kegiatan itu dilakukan dalam upaya melakukan pembicaraan tentang kekeliruan-kekeliruan guru beserta caracara pemecahannya.

Dari hasil wawancara yang dilakukan peneliti dengan kepala SMP Negeri 1 Kedungpring Kabupaten Lamongan, didapatkan bahwa didalam melaksanakan tugas-tugas kepala sekolah sebagai supervisor, kepala sekolah telah memiliki rencana kegiatan supervisi yang telah terprogram sekalipun rencana supervisi lebih banyak kepada supervisi administrasi guru dalam kelengkapan satuan pelajaran, program semester, rencana pembelajaran, dll. Adapun kegiatan yang dilakukan termasuk dalam pelaksanaan supervisi membutuhkan perencanaan yang jelas agar kegiatan yang dilakukan itu dapat berhasil guna dan berdaya guna.

Temuan yang lain dari hasil pengamatan penelitian tindakan untuk supervisi kelas yang dilakukan oleh kepala sekolah didapatkan bahwa kepala sekolah dengan cepat dan baik pemahamannya dalam menerima konsep supervisi observasi kelas yang ditawarkan oleh peneliti. Hal ini ditunjukkan dengan dengan cara kepala sekolah memberikan 
saran atau komentar kepada guru yang disupervisi dan adanya pengembangan instrumen supervisi yang disesuaikan dengan kondisi sekolahnya sehingga kegiatan supervisi benar-benar merupakan suatu bantuan untuk meningkatkan kemampuan kinerjanya.

Dari siklus ke siklus selanjutnya terjadi peningkatan kemampuan dan ketrampilan kepala sekolah dalam mensupervisi guru, setiap tahapan siklus merupakan kegiatan latihan untuk kepala sekolah dalam mensupervisi guru dengan menerapkan prinsip-prinsip supervisi observasi kelas yang disesuaikan dengan tujuan yang ingin dicapai.

Pada data frekuensi penggunaan teknik supervisi observasi kelas ditemukan bahwa, kepala SMP Negeri 1 Kedungpring Kabupaten Lamongan sering melakukan pembinaan dengan menggunakan teknik supervisi observasi kelas. Temuan ini mendukung kesimpulan Arikunto (1989) dan Hariwung (1989) bahwa supervisi yang dilakukan secara terus menerus dan berkesinambungan akan meningkatkan aspek profesionalitas guru. Kontinuitas pelaksanaan supervisi observasi kelas itu menjadi tanggung jawab kepala sekolah bagi guru-guru bawahannya.

Pada kenyataan sehari-hari kepala sekolah lah yang memiliki banyak waktu dan kesempatan untuk melakukan supervisi terhadap guru dibanding dengan pengawas sekolah, sehingga kepala sekolah memiliki porsi waktu yang besar dalam menerapkan teknik-teknik supervisi terhadap guru. Temuan ini sejalan dengan pendapat Wayson (1988) yang menyatakan bahwa tingkat keseringan (frekuensi) kepala sekolah dalam menggunakan teknik supervisi diimplementasikan dalam bentuk: mengadakan hubungan dan kerjasama yang intensif dengan guru-guru dalam memajukan pendidikan, memberi peluang pada guru-guru untuk menyediakan dan menghimpun sumber-sumber belajar, menyelesaikan masalah yang mengganggu program pendidikan dan menciptakan interaksi yang harmonis antara guru dan siswa dalam kegiatan belajar mengajar.

Temuan yang dihasilkan dari ketepatan penggunaan teknik supervisi, bahwa kepala SMP Negeri 1 Kedungpring Kabupaten Lamongan cukup baik dalam menggunakan teknik supervisi secara tepat. Temuan ini sejalan dengan Arikunto (1989) dan Hariwung (1989) yang menyebutkan bahwa teknik supervisi harus dilakukan secara tepat sesuai dengan masalah yang dihadapi, untuk menumbuhkan dan mengembangkan profesionalitas guru. Ketepatan penggunaan teknik tersebut harus dilakukan secara sistematis, obyektif, dan faktual tanpa mengenyampingkan hubungan kolegial, kekeluargaan, musyawarah, saling memberi tahu kelebihan dan kekurangan masing-masing. Oleh karena itu ketepatan penggunaan teknik supervisi perlu dilakukan secara transparan dengan memperhatikan kreatifitas dan inisiatif guru.

Pada siklus pertama, yang terjadi adalah kepala sekolah terbawa kepada pengaruh-pengaruh supervisi yang dikaitkan dengan menilai dan mencari-cari kesalahan guru, guru dianggap sebagai obyek supervisi. Kenyataan tersebut mengharuskan peneliti untuk mengajak kepala sekolah untuk berdiskusi sebelum siklus kedua dilakukan, yaitu tentang bagaimana cara membina dan membimbing guru khususnya untuk menerima kekurangan dan kelebihan masing-masing dalam rangka peningkatan kinerja guru. Ternyata hasil diskusi dapat diterapkan dengan baik pada siklus kedua dan siklus ketiga sehingga penerapan teknik supervisi benar-benar tepat sesuai dengan masalah dan kebutuhan guru.

Temuan yang dihasilkan dari data etika penggunaan teknik supervisi observasi, bahwa kepala SMP Negeri 1 Kedungpring Kabupaten Lamongan cukup 
baik dalam menerapkan teknik supervisi secara etik-profetis. Temuan ini memperkuat pendapat Gwynn (1980) yang menyatakan bahwa pendekatan manusiawi yang hangat terhadap guru harus dilakukan oleh supervisor, sehingga guru dan masalahnya merasa diperhatikan. Oleh karena itu supervisor harus berperilaku ramah dan tulus terhadap guru, memaafkan sepenuh hati atas kekeliruan guru dalam menerapkan metode pembelajaran sehingga guru merasa yakin dan dapat menetapkan pengganti metode pengajaran itu, serta memuji dan mendorong kepemilikan kinerja guru.

Pada kemampuan guru dalam perencanaan pembelajaran di SMP Negeri 1 Kedungpring Kabupaten Lamongan penyusunannya cukup baik. Dari siklus ke siklus dapat diperhatikan adanya peningkatan kemampuan perencanaan pembelajaran. Oleh karena itu setiap yang dilakukan kepala sekolah (supervisor) untuk perbaikan kinerja guru dalam hal perencanaan pembelajaran terlebih dahulu disepakati tentang bagian yang menjadi sasaran supervisi. Sehingga hubungan baik tersebut dapat menciptakan motivasi dan keinginan guru untuk disupervisi demi kebaikan perencanaan pembelajaran. Instrumen supervisi observasi kelas yang diberikan sebagai contoh oleh peneliti dapat dikembangkan sendiri oleh kepala sekolah dengan melibatkan guru sebagai salah satu bentuk kerjasama yang demokratis dalam menciptakan suatu hubungan baik.

Kenyataan yang ada di lapangan, pada siklus pertama diskusi tentang instrumen supervisi kurang diperhatikan, artinya kepala sekolah merasa bahwa instrumen supervisi tidak perlu diketahui oleh guru yang akan disupervisi. Sebelum merencanakan siklus kedua peneliti mengajak diskusi dan memberikan masukan bahwa betapa pentingnya penggunaan instrumen supervisi itu diketahui oleh guru. Menurut peneliti, hal ini perlu dilakukan oleh kepala sekolah agar anggapan supervisi observasi kelas itu menakutkan dan mencari-cari kesalahan dapat dihapuskan dan berganti dengan suasana yang menyenangkan pada saat kegiatan supervisi observasi kelas direncanakan dan dijadualkan dalam program supervisi sekolah. Pada siklus kedua ternyata hasil penggunaan supervisi menjadi lebih baik, begitu pula pada siklus ketiga terjadi peningkatan kemampuan guru dalam merencanakan pembelajaran di kelas.

Temuan yang dihasilkan dari kemampuan guru dalam proses pembelajaran, bahwa guru SMP Negeri 1 Kedungpring Kabupaten Lamongan dalam melakukan pembelajaran cukup baik, yaitu kemampuan untuk membuat murid lebih giat belajar. Kemampuan tersebut meliputi beberapa segi yaitu segi pengetahuan, ketrampilan dan sikap. Segi pengetahuan mencakup penguasaan bidang studi yang diajarkan, pengetahuan tentang berbagai metode dan alat yang dapat dipilih untuk menyampaikan materi, pengetahuan tentang murid dari sudut ilmu jiwa dan teori belajar. Segi ketrampilan dalam mengajar mencakup antara lain ketrampilan berkomunikasi, menggunakan bahasa, memilih dan menerapkan metode dan alat sesuai dengan situasi riil, ketrampilan berinteraksi, bertanya dan menyusun pertanyaan sesuai dengan kemampuan sasaran.

Sekalipun temuan yang dihasilkan kemampuan guru di SMP Negeri 1 Kedungpring Kabupaten Lamongan dalam pembelajaran cukup baik, namun pengamatan di kancah penelitian mengindisikasikan, bahwa ada guru yang masih melakukan tugas pembelajaran di kelas menggunakan metode ceramah murni, sehingga interaksi di dalam kelas belum dinamis dan kurang dapat memberikan motivasi anak untuk lebih giat belajar. 
Dari hasil pengamatan supervisi observasi kelas pada siklus pertama diketahui bahwa masih perlu adanya peningkatan kemampuan guru dalam menciptakan situasi pembelajaran yang demokratis di kelas. Artinya bagaimana guru di dalam penggunaan metode ceramah dapat dikurangi sehingga interaksi dan keterlibatan siswa lebih dominan, dan guru dipihak lain tidak lebih sebagai fasilitator saja. Untuk meningkatkan kemampuan guru dalam hal ini dibutuhkan suatu bantuan bimbingan dari kepala sekolah bagaimana pembelajaran itu berlangsung efektif dengan mengurangi metode ceramah yang panjang dan terlalu lama sehingga pembelajaran hanya terpusat pada guru.

Uraian tersebut di atas merupakan masukan dari peneliti kepada kepala sekolah sebelum merencanakan dan melakukan siklus kedua, diskusi dilakukan

\section{KESIMPULAN}

Kesimpulan yang dapat diambil sejalan dengan rumusan masalah dan tujuan penelitian ini adalah sebagai berikut: (1) Program perencanaan kegiatan supervisi observasi kelas untuk satu tahun pelajaran di SMP Negeri 1 Kedungpring Kabupaten Lamongan sudah dibuat dengan baik oleh kepala sekolah pada awal tahun pelajaran. Demikian pula frekuensi pelaksanaan supervisi observasi kelas disesuaikan dengan jadual guru mengajar dan diatur dalam tiap semester pada satu tahun pelajaran. (2) Etika penggunaan teknik supervisi yang dilakukan oleh kepala sekolah dan guru ketika selesai disupervisi, kepala SMP Negeri 1 Kedungpring Kabupaten Lamongan selalu menunjukkan sikap penuh persahabatan kekeluargaan terutama pada saat-saat mendiskusikan hasil pengamatan supervisi observasi kelas. Suasana kekeluargaan kalaupun ditemukan kelemahan ataupun kekurangan guru pada saat pembelajaran berlangsung, kepala sekolah berusaha dengan memberikan contoh-contoh, memotivasi guru agar dalam pembelajaran yang dilakukan berlangsung efektif dan demokratis. Kenyataan yang ada pada hasil pengamatan dari siklus kedua dan ketiga terjadi peningkatan pemahaman kepala sekolah sehingga kemampuan guru dalam proses pembelajaran meningkat dengan baik.

Uraian tersebut di atas menunjukkan betapa kepala sekolah sudah berusaha untuk memperbaiki dan meningkatkan kemampuan dan ketrampilan dengan melakukan pembinaan dan bimbingan kepada para guru dalam kaitannya dengan peningkatan para guru melakukan pembelajaran di kelas sampai dapat terwujud dengan baik. Dengan demikian hasil pengamatan penelitian tindakan yang dilakukan peneliti pada siklus ketiga, apa yang diharapkan oleh peneliti dapat tercapai dengan baik.

untuk memahami keterbatasan ataupun kekurangan guru dan memaafkan kemudian memberikan solusi berupa bimbingan ataupun pembinaan agar kekeliruan atau kekhilafan tidak terjadi pada pertemuan pembelajaran berikutnya.

(3) Pelaksanaan kegiatan supervisi pengajaran dengan teknik observasi kelas yang dilakukan oleh kepala SMP Negeri 1 Kedungpring Kabupaten Lamongan sudah sesuai dengan prinsip-prinsip supervisi observasi kelas. Hal ini dapat dilihat dari perkembangan peningkatan dari siklus ke siklus, yaitu mengenai: Program perencanaan supervisi, frekuensi pelaksanaan observasi kelas, ketepatan penggunaan teknik supervisi observasi kelas, serta etika penerapan supervisi observasi kelas. (4) Kemampuan guru SMP Negeri 1 Kedungpring Kabupaten Lamongan dalam perencanaan pembelajaran ketika disupervisi oleh kepala sekolah menunjukkan rata-rata peningkatan yang baik dari siklus ke siklus. Peningkatan tersebut meliputi aspek-aspek: cara menetukan bahan 
pelajaran, memilih dan mengorganisasikan materi, merancang skenario pembelajaran, merancang pengelolaan kelas, serta merancang prosedur dan mempersiapkan alat evaluasi. (5) Kemampuan guru SMP Negeri 1 Kedungpring Kabupaten Lamongan dalam proses pembelajaran di kelas ketika disupervisi oleh kepala sekolah melalui supervisi observasi kelas menunjukkan peningkatan yang baik dari siklus ke siklus. Peningkatan tersebut meliputi aspek-aspek: mengelola ruang, waktu dan fasilitas belajar, aspek menggunakan strategi pembelajaran, mengelola interaksi kelas, mengembangkan sikap positif siswa terhadap belajar, serta aspek melaksanakan evaluasi proses dan hasil belajar.

\section{DAFTAR PUSTAKA}

Ali Imron, 2009, Pembinaan Guru di Indonesia, Jakarta, PT Dunia Pustaka Jaya.

Arikunto, Suharsimi, 2009, Penilaian Program Pendidikan, Jakarta, Proyek Pengembangan LPTK, Dirjen Kemdikbud.

Bolla, JL, 1985, Supervisi Klinik, Direktorat Pendidikan Tinggi, Departemen Pendidikan dan Kebudayaan, Jakarta, P3TK.

Hariwung, A.J., 2011, Supervisi Pendidikan, Jakarta, Depdikbud.

Kemdiknas, 2007, Alat Penilaian Kemampuan Guru, Dirjen Dikdasmen, Direktorat Pendidikan Guru dan Tenaga Teknis, Jakarta.

Natawijaya, Rochman, (2007), Konsep Dasar Penelitian Tindakan, Jakarta, Depdikbud, Dirjen Pendidikan Tinggi, Bagian Proyek Pengembangan
Pendidikan Guru

Nawawi, Hadari, 2011, Administrasi Pendidikan, Jakarta, PT Gunung Agung.

Pidarta Made, 2012, Pemikiran Tentang Supervisi Pendidikan, Jakarta, Bumi Aksara.

Sahertian Piet A, 2010, Konsep Dasar dan Teknik Supervisi Pendidikan, Jakarta, Reineka Cipta. 